\title{
A Meta-Synthesis Study for Researches on Citizenship Education within the Scope of Social Studies Course in Turkey
}

\section{Türkiye'de Sosyal Bilgiler Dersi Kapsamında Vatandaşlık Eğitimine İlişkin Gerçekleştirilen Araştırmalara Yönelik Bir Meta-Sentez Çalışması}

\section{Burcu SEL*}

Received: 12 February 2021

Research Article

Accepted: 27 April 2021

\begin{abstract}
In this research, the purpose is to develop a systematic perspective on the research on citizenship education within the scope of social studies field, to reveal the tendency of the studies, and to reach a synthesis in this direction. Meta-synthesis method was used for this purpose. Researches on "citizenship" were collected and reviewed according to certain criteria, and then the reading process was repeated in order to identify the relationships between the researches, similar, different aspects were identified by using perspective-based continuous comparison, and a synthesis has been reached based on the obtained findings. The researches were obtained from National Thesis Center of the Council of Higher Education and Ulakbim TRDizin. During the analysis of the data process, thematic synthesis and descriptive analysis were utilized. Three main themes were reached: citizenship types/approaches, citizenship perception, and components of citizenship education. Citizenship types/approaches are addressed as spatial, environmentally responsible, effective/effectual/active citizenship, global and digital citizenship. In the context of citizenship perception, it is seen that the subjects of meaning attributed to citizenship, citizenship awareness/identity construction, good/ideal citizen, patriotism are taken as a basis. Under the main theme of components of citizenship education, three sub-themes were generated: basic elements in citizenship education, approaches in citizenship education, and problems in citizenship education. It can be suggested to examine the factors that cause the formation of nationalist and socialist citizenship perception, which is frequently encountered in the studies examined. In addition, comparative studies can be carried out by expanding the databases.
\end{abstract}

Keywords: Citizenship education, meta-synthesis, social studies.

ÖZ: $\mathrm{Bu}$ araştırmada sosyal bilgiler kapsamında vatandaşlık eğitimi temelinde gerçekleştirilen araştırmalara sistematik bir bakış açısı geliştirmek, araştırmaların nasıl bir eğilim içerisinde olduğunu ortaya koymak ve bu yönde senteze varmak amaçlanmıştır. Metasentez yönteminden yararlanılarak "vatandaşlık" konulu araştırmalar belirli kriterler dâhilinde toplanmış, ön okumadan geçirilmiş, ardından araştırmaların nasıl bir ilişsi içerisinde olduğunu belirleyebilmek adına okuma süreci tekrarlanmış, sürekli karşılaştırmaya dayalı bakış açısından yararlanılarak benzer ve farklı yönler tespit edilmiş, elde edilen bulgulardan yola çıkılarak senteze ulaşılmaya çalışılmıştır. Veriler YÖK Ulusal Tez Merkezi ve Ulakbim TRDizin aracılığıyla elde edilmiştir. Veri analizi sürecinde tematik sentezleme ve betimsel analizden faydalanılmıştır. Metasentez süreci sonunda vatandaşlık türleri/yaklaşımları, vatandaşlık algısı ve vatandaşlık eğitiminin temel bileşenleri olmak üzere üç ana temaya ulaşılmıştır. İlk olarak vatandaşlık türleri/yaklaşımları ana teması mekânsal, çevresel sorumlu, etkili/aktif vatandaşlık, küresel ve dijital vatandaşlık; ikinci olarak vatandaşlık algısı ana teması vatandaşlığa yüklenen anlam, vatandaşlık bilinci/kimlik inşası, iyi/ideal vatandaş, vatanseverlik/yurtseverlik ve son olarak vatandaşlık eğitiminin bileşenleri ana teması ise vatandaşlık eğitiminde temel unsurlar, vatandaşlık eğitiminde kullanılan yaklaşımlar ve vatandaşlık eğitiminde yaşanan sorunlar olmak üzere alt temalara ayrılarak değerlendirilmiştir. İncelenen araştırmalarda yoğunlukla ele alınan ulusalcı ve toplumsalcı vatandaşlık algısının oluşmasına neden olan faktörlerin incelenmesi önerilebilir. Bununla birlikte veri tabanları genişletilerek karşılaştırmalı araştırmalar yürütülebilir.

Anahtar kelimeler: Vatandaşlık eğitimi, meta-sentez, sosyal bilgiler.

* Dr., Republic of Turkey Ministry of National Education, Ankara, Turkey, burcusel3@gmail.com, https://orcid.org/0000-0002-7663-0434

Citation Information

Sel, B. (2021). A Meta-synthesis study for researches on citizenship education within the scope of social studies course in Turkey Kuramsal Eğitimbilim Dergisi [Journal of Theoretical Educational Science], 14(3), 323-351. 
Theories of citizenship, which have been in philosophy since Aristotle and Plato, often have very different meanings than we can apply today (Leighton, 2004, p. 169). The center in the most recent developments in citizenship discourses has changed from definitions that emphasize legal, civic, and political constituents to social constituents such as identity, virtue, civic attitudes, and knowledge (Nabavi, 2010, p. 2). The increasing ethnic, cultural, racial and religious diversity in the world obliges citizenship education to be modified in important ways to effectively prepare students in the $21 \mathrm{st}$ century (Banks, 2001, p. 6). "Both the concept of citizenship and citizenship education have gone through a transformation in the last 20 years as policymakers, academicians, and citizens tried to deal with the consequences of globalization, increasing immigration, and new information and communication technologies" (Keating, 2016, p. 35). In addition, nearly the last two decades, school systems around the world appear to have undergone numerous reform measures designed to reorient and/or strengthen the role of citizenship education, including the introduction of new school subjects and cross-curricular themes (under a range of curriculum tags, including citizenship, civic knowledge, democratic education, national education, and political education) in many countries, and major reforms in the existing curriculum (Johnson \& Morris, 2010, p. 77). Various changes and transformations in this context have made it necessary to develop a renewed perspective on both the definition of citizenship and the nature of citizenship education.

Since citizenship education is closely related to the legitimacy of the nationstate, various institutions and citizenships pose a significant challenge to the content of the national curriculum, as well as the traditional goals and assumptions of citizenship education (Keating et al., 2009, p. 145). While citizenship education generally focuses on the closeness of the nation and citizens to the nation-state, cosmopolitanism in this global age, on the other hand, challenges this by emphasizing the primary commitment to humanity and/or planet Earth (Osler, 2011, p. 1). "The increasing racial, ethnic, cultural, linguistic, and religious diversity in the nation-state around the world raises new and complex questions about educating students for effective citizenship" (Banks $\&$ Nguyen, 2008, p. 137). Since the nation-states first institutionalized schooling, the meanings of the concept of "citizenship" in terms of educational practices have been built over time and through cultural struggles (Abowitz \& Harnish, 2006, p. 653). As the meaning of citizenship is shaped, it is also seen the concept of citizenship has various dimensions. In this direction, different dimensions of citizenship are stated as legal status, political and civil rights, identity, social and economic rights, competence and skills, values, culture, and behaviors (Keating, 2016, p. 37). In addition, Hébert and Sears (2001) stated that there are four main areas of citizenship, namely the civil, political, socio-economic, and cultural or collective dimensions; they state that the first three of these were identified by T.H. Marshall after WWII, while the fourth emerged later, and that these four areas of citizenship are in a complex interaction in a dynamic and global context.

\section{Citizenship Education and Social Studies}

It is seen that the concept of citizenship offers "membership, identity, values and participation" rights, at least theoretically, and undertakes a common political knowledge (Abowitz \& Harnish, 2006, p. 653). Citizenship refers to the relationship 
between the individual and the state and those within the state, while citizenship education is accepted as the preparation of individuals to participate in democracy as active and responsible citizens (Hébert \& Sears, 2001). There has been a notable increase in interest in citizenship education over the past decade (Sim, 2008, p. 253). When the last decade is examined, the intense interest in sociological, political and legal literature on citizenship parallels the policies aimed at expanding the scope of citizenship education in many countries (Brooks \& Holford, 2009, p. 1).

\begin{abstract}
Interest in citizenship education has increased worldwide over the past decade. Some see this dimension of education as an opportunity to prepare the youth from local to global to understand and be involved in the civic life of communities. Others see it as a way of responding to a range of social and civic concerns. Regardless of the reason(s), there has been an increase in worldwide research, formal debates, and curriculum initiatives as teachers, policymakers and researchers try to understand and evaluate the complex processes that young people learn about democratic citizenship. (Evans, 2006, p. 411)
\end{abstract}

Since the 19th century, one of the most fundamental models of modern citizen building has been recognized as the extension of formal education through the establishment and development of education systems supported both publicly (state) and privately (Fischman \& Haas, 2012, p. 171). Citizenship education, in one way or another, has been observed in every society as a comprehensive goal throughout history (Sim \& Print, 2005, p. 58) and as one of the core responsibilities of public schools (Sears \& Hughes, 1996, p. 123). When contemporary modern societies are examined, it is stated that schools are obliged to provide citizenship education based on the assumption of the critical role of schools in the development of citizenship (Geboers et al., 2013, p. 169). Policymakers hope that schools will build children's citizenship perspectives (Eidhof et al., p. 123). Since the responsibility of socializing the new generation to become a nation-state is of great importance, many governments have given this task especially to schools (Sim \& Print, 2005, p. 58). Many governments around the world aim to develop citizenship education programs based on schools (Brooks \& Holford, 2009, p. 12). "Furthermore, citizens' values, attitudes and behaviors are learned not inherited, and schools play an important role in informing children and young people about the formal and informal rules of citizenship, and in preparing them for their role as citizens" (Keating, 2016, p. 35). Citizenship education has been accepted as the main duty or obligation of schools since the past due to ideological, political, economic, and social concerns, and it has been tried to be controlled especially by the sovereign powers. In this sense, citizenship education is a basic obligation that takes place in a controlled and supervised manner.

"Citizenship education may be defined as any conscious or overt effort to develop students' knowledge of government, law, and politics as those have evolved through history and presently operate in our society" (Hoge, 2002, p. 105). Citizenship education is broadly interpreted to include the preparation of young people for their roles and responsibilities as citizens and especially to include the role of education (through education, training, and learning) in this preparation process (Kerr, 1999, p. 6). The basis of this education is the belief that the state is responsible for conveying fundamental values and that these values belong to the public sphere (Osler \& Starkey, 2004 , p. 4). In general, the main goal of citizenship education is to encourage and support people to play a better democratic role (Davies et al., 2005, p. 342). 
Citizenship education is a broad field that includes a wide range of philosophical, political, and ideological perspectives and pedagogical approaches, goals, and practices. At the most abstract level of discourse, there is a general consensus that the primary goal of citizenship education is the development of good democratic citizens. This goal is expressed in different ways in terms of implementing educational policies, curriculum development, and pedagogical strategies. As a matter of fact, citizenship education, like other educational fields, has conservative and progressive orientations. Citizenship education can be used as a tool to maintain the status quo as well as empower individuals and groups to fight for emancipatory change. While citizenship education practices are located somewhere along the continuum of these two orientations, they tend to gravitate towards one or the other. (Schugurensky \& Myers, 2003, p. 1-2)

Considering citizenship education in terms of curriculum, it is seen that social studies course offers a wide theoretical ground. The social studies curriculum is largely responsible for citizenship education; here it is usually found as a separate area or focus within the scope of primary school social studies curriculum, and is represented everywhere in the secondary and high school social studies curriculum as one or more subjects in the field of government or citizenship (Hoge, 2002, p. 105). "Teaching social studies as a social science is based on the assumption that acquiring the knowledge, skills and values of social sciences is the best preparation for effective citizenship" (Yalçın \& Akhan, 2019, p. 844). Social studies course is mainly taught as a component of the process of transferring simplified social sciences and citizenship values (Sim \& Print, 2005, p. 70). It is stated that there is a consensus that the basic goal of social studies is citizenship education or preparing young people to have the knowledge, skills and values necessary for effective participation in society (Ross, 2004, p. 249). The National Council for the Social Studies [NCSS] defines an effective citizen as someone who has the knowledge, skills, and attitudes necessary to assume the 'seat of citizenship' in the democratic republic (NCSS, 2001). Through the social studies course, which undertakes the role of citizenship transfer, students are able to socialize towards a certain set of values and knowledge at both cognitive and affective levels by focusing on the nation, common culture and shared values (Sim \& Print, 2005, p. 70). "In today's global environment, social studies educators have the opportunity to expand their students' vision of the role of citizenship in developing a democratic understanding by adopting multiple perspectives on citizenship" (Rapoport, 2009, p. 91). In this context, when the social studies curriculum in Turkey in 2018 is examined, it is seen that citizenship-related competencies are identified and the new developments regarding the rights and responsibilities of citizenship are included. In addition, in the curriculum, "active citizenship" is included in the 4th, 5th, 6th, and 7th grades as a learning field (Ministry of National Education [MEB], 2018).

Citizenship education consists of different elements and conflicts in various contexts. Although the same factors agree on "knowledge-skills and values", there is broad disagreement about each factor's function, nature, and relative importance (Hébert \& Sears, 2001). As democratic societies continue to face a variety of social and civic issues, it is vital to carefully define what citizenship is and how education can contribute to the formation of good citizens (Eidhof et al., 2016, p. 125). While research on citizenship education has become a qualified academic sub-discipline, it is interesting to examine the academic changes of citizenship education in the last fifty years (Veugelers \& de Groot, 2019, p. 15). "While many citizenship scholars seem broadly aware that "citizenship" is of growing importance in educational curricula, few have attempted any systematic exploration of what this might imply" (Brooks \& 
Holford, 2009, p. 2). Approaching the research conducted in Turkey on citizenship education with a holistic and systematic perspective is important, especially in order to reveal the current situation of these studies at a national level, as well as to present a projection for the future. In this context, Som and Karataş (2015), which examined the status of citizenship education in primary and secondary education level in Turkey. This research was carried out within the scope of the "Citizenship Education in Europe" report. As a result of the research, the dimensions of the curriculum and organization, student and parent participation at school, student participation in society, assessment and evaluation, and support for teachers and principals were reached. In the research conducted by Kayaalp and Karameşe (2020), which examines the trends in the theses on "citizenship" prepared within the scope of social studies education, the type of theses, the year of publication, the citizenship issues in the theses, their aims, research approaches, working groups, data collection tools, data analysis types, research results are included. In the study conducted by Sönmez et al. (2009), it was tried to reveal the subjects and methods that were taken as a basis in the studies conducted on citizenship and human rights education. Also, Merey et al. (2012) compare the citizenship education in Turkey and in the USA. This comparison is made in terms of learning areas, acquisitions, skills, content and values in the social studies curriculum. In this study, citizenship education was limited within the scope of "social studies". It was tried to produce comments based on integrative findings rather than descriptive features present in articles and theses. Considering the important role of the social studies lesson within the scope of citizenship education, it is crucial to reveal the similarities and differences, relations, tendencies, inclusion/exclusion of the subjects, and the descriptive features in the research. In this study, the purpose is to develop a systematic perspective on the research on citizenship education within the scope of social studies field, reveal the studies' tendency, and reach a synthesis in this direction. In this context, the following sub-problems were attempted to be answered: In the citizenship education research within the scope of social studies courses in Turkey:

How diverse are the research methods used (research model/design, research group, data collection tools, data analysis, suggestions)?

How diverse are the underlying issues?

How have the results been shaped?

\section{Method}

In this research, meta-synthesis method was utilized. Meta-synthesis is expressed as a type of research integration study in which findings related to completed qualitative studies are synthesized (Sandelowski \& Barroso, 2003, p. 907). Since the synthesized data is beyond the primary research conducted in a qualitative context, it contains differences from other studies (systematic, narrative) and meta-analysis (Mohammed et al., 2016, p. 696). "Qualitative meta-syntheses are more than just compilations and descriptive summaries of thematically interrelated qualitative studies" (Schwarz et al., 2018, p. 29). Meta-synthesis is not a holistic evaluation of qualitative literature on a particular topic or a secondary data analysis of primary data from a number of selected studies; rather, it is defined as an analysis of the findings of these studies (Zimmer, 2006, p. 312). The main purpose of meta-synthesis is to develop both a holistic and new interpretation, which is more robust than the data obtained as a result 
of individual research (Finfgeld, 2003, p. 894). "In summary, bringing together qualitative studies in a related area enables the nuances, taken-for-granted assumptions, and textured milieu of varying accounts to be exposed, described and explained in ways that bring fresh insights" (Walsh \& Downe, 2005, p. 205). Regarding the synthesis process, the following steps are recommended (Noblit \& Hare, 1999, p. 110-112).

Step 1: Getting Started; identifying an intellectual interest that can be examined qualitatively.

Step 2: Selecting the studies related to the initial interest.

Step 3: Reading the studies.

Step 4: Identifying how the studies are related to each other.

Step 5: Transforming/comparing the data.

Step 6: Synthesizing the transformed data.

Step 7: Interpreting/expressing the synthesis.

In this study, similar to one of Noblit and Hare (1999), first, studies on "citizenship" were collected and reviewed according to certain criteria. Then the reading process was repeated to identify the relationships between the studies, similar and different aspects were identified using perspective-based continuous comparison. A synthesis has been reached based on the obtained findings.

\section{Selection of Studies}

There is no consensus on which data sources are best for meta-synthesis process (Finfgeld, 2003, p. 898). One of the problems in conducting qualitative meta-synthesis research is deciding which of thematically similar studies to include in the process. The large sample size (as in any qualitative research) both prevents deep analysis and therefore threatens interpretative validity (Sandelowski et al., 1997, p. 368). It is important in this respect that data sources are selected in sufficient number and quality. In this study, the collection of research data was started on 19.07.2020 and ended on 20.08.2020. In this context, the words citizenship, civics, citizenship education and social studies have been selected as keywords, primarily in English and Turkish. The studies in National Thesis Center of the Council of Higher Education (https://tez.yok.gov.tr) and Ulakbim TRDizin (https://trdizin.gov.tr/) were listed within this context and included in the research according to certain criteria. Primarily, the year range was selected as 2005-2020 within the scope of screening. One of the main reasons for selecting this period of time is the comprehensive revision of social studies curricula in 2005, and approaching 2020, the changes in perception of citizenship and the formation of different conceptual perspectives such as the digital, global, transnational, active, spatial citizenship that emerged in citizenship approaches. In addition, due to the nature of meta-synthesis research, attention has been paid to the fact that the research is carried out with a qualitative or mixed perspective. The criteria in this context are as follows:

Studies should be about citizenship education within the scope of social studies course,

The research should be conducted with qualitative approach,

The study should be published between 2005 and 2020, 
Clear, understandable, and unequivocal reporting of scientific processes involved in research.

Figure 1

Selection Process of Studies for Meta-Synthesis

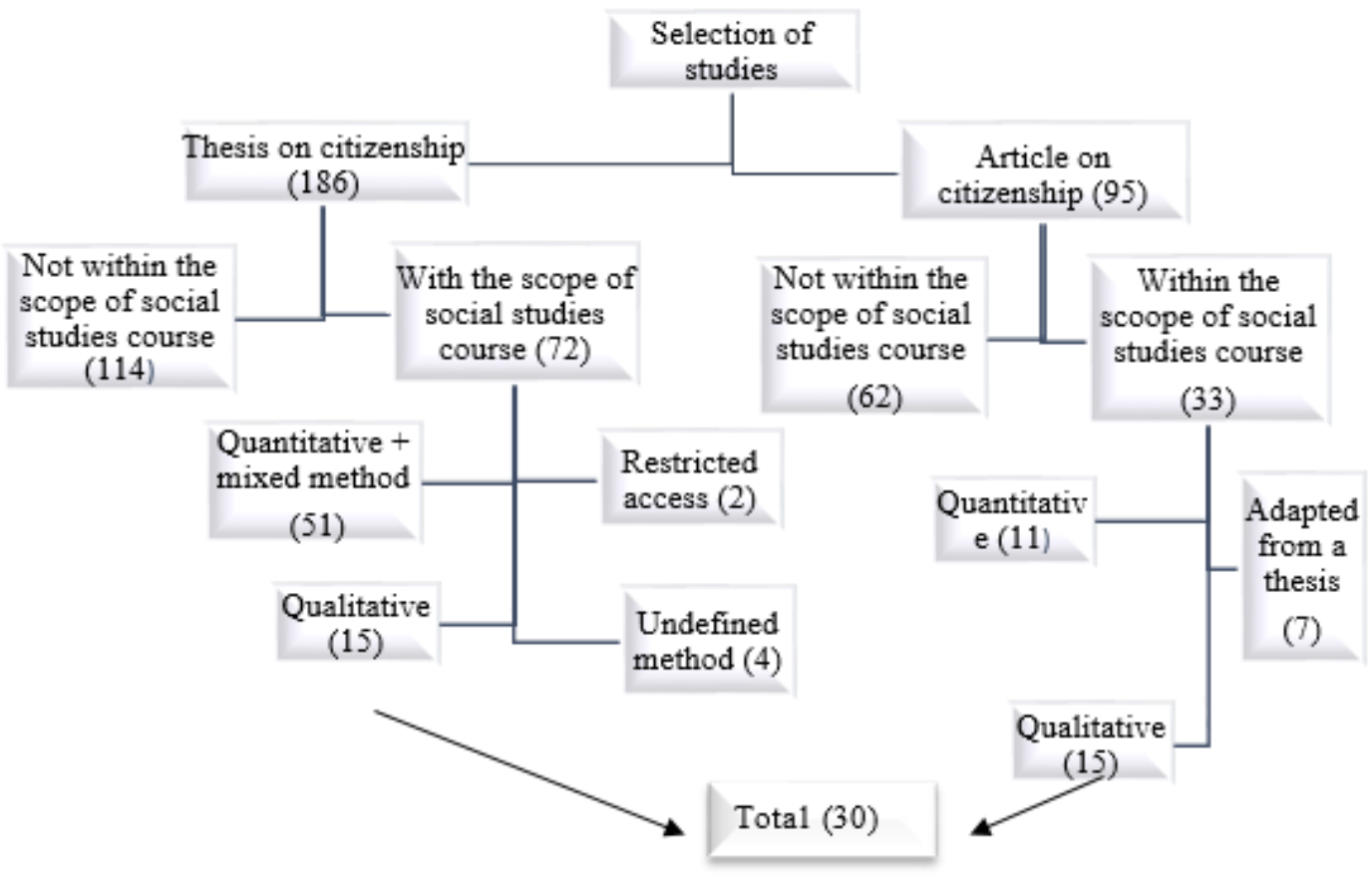

A total of 281 studies were accessed within the scope of citizenship education between the specified years; it has been observed that 105 of these studies were conducted within the scope of the "social studies" course on citizenship education. However, it was seen that 47 of these studies were conducted with a quantitative method, the method section of four of them was not clearly and distinctly reported, two theses were restricted by the author, and seven theses were transformed from thesis to article. Therefore, a total of 30 pieces of research, including 11 master's theses, 4 doctoral dissertations, and 15 articles meeting all criteria were included in the metasynthesis process. The doctoral dissertations included in the meta-synthesis were coded as "D1, D2, D3..." the master's theses as "M1, M2, M3...", and articles as "A1, A2, A3..."

\section{Data Analysis}

The data analysis was carried out in a period of about five months, and during this process, thematic synthesis and descriptive analysis were utilized. In this context, all studies were reviewed by considering the sub-problems of the research during the data analysis; the code, title, author(s), year of publication, type (master's/doctorate), purpose, method, participants, data collection, data analysis, findings (similar/different themes), and results of each study was recorded in a chart. In order to preserve the integrity of each study in the synthesis process, the studies should be analyzed in detail in a balanced way and there should not be an overwhelming amount of detail, which will prevent a usable synthesis (Sandelowski et al., 1997, p. 370). In this direction, all studies were reviewed and coded digitally on a chart, an example of which can be seen in Figure 2. 
Figure 2

The First Form Used in The Reviewing Process

\begin{tabular}{ll}
\hline Code: & \\
\hline Research name: & \\
\hline $\begin{array}{l}\text { Researcher's name and } \\
\text { surname: }\end{array}$ & $\begin{array}{l}\text { Publication year of the } \\
\text { research: }\end{array}$ \\
\hline Type of research: & \\
\hline & Purpose of the research: \\
\hline
\end{tabular}

\begin{tabular}{l}
\hline \multicolumn{1}{c}{ Method of research: } \\
\hline Source of data: \\
\hline Data collection tools: \\
\hline Data analysis \\
\hline Results: \\
\hline
\end{tabular}

Then, the second reading process was started and the data transferred to the form was double-checked. After the review of the studies was completed and their data was transferred to the chart developed as a data collection tool, the data in the said form was started to be examined by considering the similarities and differences. In this context, possible codes, candidate sub-themes, and main themes were started to be formed after a third reading was carried out. Afterward, the codes and themes created were presented to expert opinion and the process was repeated and the main/sub-themes were reached.

\section{Ensuring Validity and Reliability}

In the validation process of meta-synthesis, the criteria for inclusion, data processing, collection procedures, sample explanation, data analysis and interpretation should be clear (Bondas \& Hall, 2007, p. 119). In this context, the method, data collection (inclusion or exclusion criteria in the study), data analysis processes and findings were explained in detail during the validation process. "Clear descriptions of sampling and data analysis decisions will also increase the credibility of findings" (Finfgeld, 2003, p. 902). Therefore, detailed explanations regarding each study included in the study were presented and the findings were also presented in detail. In addition, the forms/documents accessed or prepared during the data collection and analysis process were filed and saved for confirmation when necessary.

Kuckartz (2014) also draws attention to the "cooperative approach called consensual coding" in this process. It emphasizes that consensual coding will increase the quality of the research and increase the reliability of the coding. He states that in the first stage of consensual coding, two or more encoders encode the data independently. In the second step, the coders check the similarities and differences of the codes together and aim to reach a consensus on the most appropriate coding. In terms of reliability, two experts in the field of classroom/social studies education were consulted periodically regarding the codes and themes created in the analysis of the data. Various corrections and arrangements were carried out in the themes by evaluating the opinions 
received. In this context, evaluations were made on two randomly selected data sets in the last expert review. Supporting the inferences with various raw data, in other words, with quotations, increases the reliability of the findings (Finfgeld, 2003, p. 902). In this context, the findings obtained are frequently presented with direct quotations.

\section{Results}

\section{Descriptive Analysis Results}

Research patterns/models, study groups/participants, data collection tools, and data analysis methods taken as a basis in the studies on citizenship education within the scope of social studies course were analyzed. The research designs/models used in the studies examined in this direction are given in Table 1:

Table 1

Research Patterns/Models Used in Studies

\begin{tabular}{ll}
\hline \multicolumn{1}{c}{ Research Patterns/Models } & \multicolumn{1}{c}{ Study } \\
\hline Basic Qualitative/Qualitative Method & M1, M3, M10, A3, A6, A7, A9, A11 \\
\hline Phenomenology & M2, M4, M11, A1, A12, A13, A15 \\
\hline Case Study & D2, M5, M8, A2, A5, A8, A14 \\
\hline Action Research & D3, D4, M6, M7 \\
\hline Historical Research & M9 \\
\hline Narrative Inquiry & D1 \\
\hline Hermeneutic Research & A4 \\
\hline Critical Discourse Analysis & A10 \\
\hline
\end{tabular}

It is seen that the studies examined include narrative inquiry, basic qualitative research, case study, phenomenology, action research, historical research, hermeneutic research, and critical discourse analysis. However, most of the studies were carried out by adopting the basic qualitative research design, case study and phenomenological research. Narrative inquiry, historical research, hermeneutical research, and critical discourse analysis studies were used less frequently.

Descriptive findings regarding the participants/study groups or data sources used in the studies examined are given in Table 2.

Table 2

Data Sources Used in The Studies

\begin{tabular}{lll}
\hline \multicolumn{1}{c}{ Theme } & \multicolumn{1}{c}{ Code } & \multicolumn{1}{c}{ Study } \\
\hline $\begin{array}{l}\text { Teacher and Teacher } \\
\text { Candidate }\end{array}$ & Social Studies Teacher & D2, M1, M2, M3, M8, M10, A3, A7, \\
& A9, A14 \\
\cline { 2 - 3 } & Social Studies Teacher Candidate & D1, D4, M5, M6, M8, A1, A5, A11, \\
& A12, A13, A15 \\
\cline { 2 - 3 } & Expert Lecturer & M11 \\
\hline
\end{tabular}




\begin{tabular}{lll}
\hline Expert/Academician & Field Expert/Faculty Member & A7, M11 \\
\hline Student & Secondary School Student & D3, M4, A2, A8 \\
\cline { 2 - 3 } & Primary School Student & M7 \\
\hline Document & Curriculum & A6, A10 \\
\cline { 2 - 3 } & Textbook & M9, A6 \\
\hline
\end{tabular}

It is seen that four themes have emerged: teacher and teacher candidate, expert/academician, student, and document. In this context, social studies teacher candidates ranked first, and social studies teachers ranked second. On the other hand, primary school students and expert lecturers were the least involved in these studies.

Descriptive findings regarding the data collection tools used in the studies are given in Table 3.

Table 3

Data Collection Tools Used in The Studies

\begin{tabular}{lll}
\hline \multirow{2}{*}{ Theme } & \multicolumn{1}{c}{ Code } & \multicolumn{1}{c}{ Study } \\
\hline \multirow{2}{*}{ Interview } & Semi-Structured Interview Form & D1, D2, D3, M1, M2, M3, M4, M5, M6, \\
& & $\begin{array}{l}\text { M7, M8, M10, A1, A3, A5, A7, A9, A13, } \\
\text { A14, A15 }\end{array}$ \\
\cline { 2 - 3 } & Structured Interview & M11 \\
\cline { 2 - 3 } & Focus Group Meeting & D3 \\
\hline \multirow{2}{*}{ Observation } & Video, Record, Photograph & D3, D4, M6 \\
\cline { 2 - 3 } Journal & Participant Observation & M1, M6, A14 \\
\cline { 2 - 3 } & Researcher Journal & D3, D4, M6 \\
\cline { 2 - 3 } Document & Student Journal & D3, A1 \\
\cline { 2 - 3 } & Open-Ended Question Form /Survey & M6, M7, D3, D4, A2, A8, A9, A11, A12 \\
\cline { 2 - 3 } & Document Analysis /Examination & D2, M19, A6, A14 \\
\cline { 2 - 3 } & Course Evaluation Form & D4 \\
\cline { 2 - 3 } & Concept Map Sheet & M7 \\
\cline { 2 - 3 } & Worksheet & M7 \\
\cline { 2 - 3 } & Practice Report & A1 \\
\cline { 2 - 3 } & &
\end{tabular}

It is seen that the data collection tools used in the studies examined are interview, observation, journal, and documents. In this context, the most frequently used data collection tools were the semi-structured interview form under the interview theme and the open-ended question form/survey under the document theme.

Descriptive findings related to data analysis methods used in studies included in the meta-synthesis process are given in Table 4. 
Table 4

Data Analysis Methods Used in The Studies

\begin{tabular}{|c|c|c|}
\hline Theme & Code & Study \\
\hline \multirow{9}{*}{ 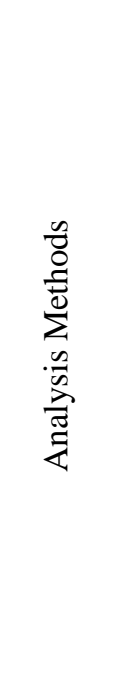 } & Content Analysis & $\begin{array}{l}\text { D2, D3, D4, M1, M2, M4, M6, M8, M10, } \\
\text { A4, A6, A7, A8, A9, A11, A12 }\end{array}$ \\
\hline & Descriptive Analysis & $\begin{array}{l}\text { D4, M4, M5, M6, M7, M9, M11, A2, A3, } \\
\text { A5, A11 }\end{array}$ \\
\hline & Thematic Analysis & D4, M3, A13, A14 \\
\hline & Problem Solution/Narrative Analysis & D1 \\
\hline & Holistic Structural Analysis & D1 \\
\hline & Document Examination & D2 \\
\hline & Phenomenological Analysis & A1 \\
\hline & Critical Discourse Analysis & A11 \\
\hline & Inductive Analysis & A15 \\
\hline
\end{tabular}

It is seen that content analysis, problem solution/narrative analysis, holistic structural analysis, document analysis, thematic analysis, descriptive analysis, inductive analysis, phenomenological analysis, critical discourse analysis, and inductive analysis are used as data analysis methods in the studies examined. In this context, the most frequently used analysis method was content analysis and descriptive analysis.

Findings regarding the recommendations developed in the studies included in the meta-synthesis process are given in Table 5.

\section{Table 5}

Recommendations in The Studies

\begin{tabular}{|c|c|c|}
\hline Theme & Code & Study \\
\hline \multirow{8}{*}{ 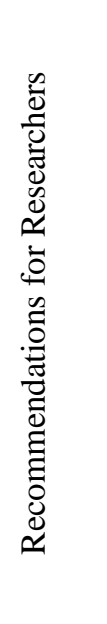 } & Research Using Mixed and Quantitative Methods & $\begin{array}{l}\text { D2, M1, M2, M3, M4, M8, M10, } \\
\text { A5, A9 }\end{array}$ \\
\hline & Research Involving Different Participants & $\begin{array}{l}\text { D2, M2, M3, M5, M8, M10, A2, } \\
\text { A3 }\end{array}$ \\
\hline & Research on The Sociocultural Dimension of Citizenship & $\mathrm{D} 2, \mathrm{D} 3, \mathrm{M} 1, \mathrm{~A} 2$ \\
\hline & International Comparative Research & $\mathrm{D} 2, \mathrm{M} 9, \mathrm{~A} 2, \mathrm{~A} 5$ \\
\hline & Textbook-Based Research & M1, M9, M10 \\
\hline & Curriculum-Based Research & M1, M9, M11 \\
\hline & Research Based on Expert Opinions & M1, M8 \\
\hline & Research Based on Conceptual Problems & M8 \\
\hline \multirow{3}{*}{ 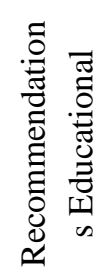 } & Teacher Training & $\begin{array}{l}\text { D1, D3, D9, M2, M3, M7, M10, } \\
\text { A9, A11, A14 }\end{array}$ \\
\hline & Curriculum Planning and Change & $\begin{array}{l}\text { D3, D9, M1, M2, M3, M5, M7, } \\
\text { A13 }\end{array}$ \\
\hline & Making Changes to the Textbook & D3, M2, M7, M8, A9 \\
\hline
\end{tabular}




\begin{tabular}{ll} 
Cooperation between Various Institutions & D3, M3, M6, M11, A1 \\
\hline Paying Attention to the Sociocultural Environment & D3, D9, A8, A13 \\
\hline Family Education & M3, M8, A9 \\
\hline Improving School Infrastructure and Physical Conditions & D3, M3 \\
\hline Paying Attention to Out-of-School Activities & D3, M6
\end{tabular}

It is seen that two themes have emerged in the investigated studies, namely, suggestions for researchers and educational practice. In recommendations for researchers, using mixed and quantitative methods ranked first. Teacher training ranked first in recommendations on educational practices. On the other hand, research based on conceptual problems were the least involved in these studies.

\section{Results of Meta-Synthesis}

The results obtained from the studies on citizenship education within the scope of social studies course were synthesized; In this context, the main and sub-themes were reached, direct quotations were made about the themes, and the findings obtained as a result of the meta-synthesis were supported. Three main themes have been reached: citizenship types/approaches, citizenship perception, and components of citizenship education. These main and sub-themes are given in Figure 3.

Figure 3

Main and Sub-Themes Reached as a Result of Meta-Synthesis

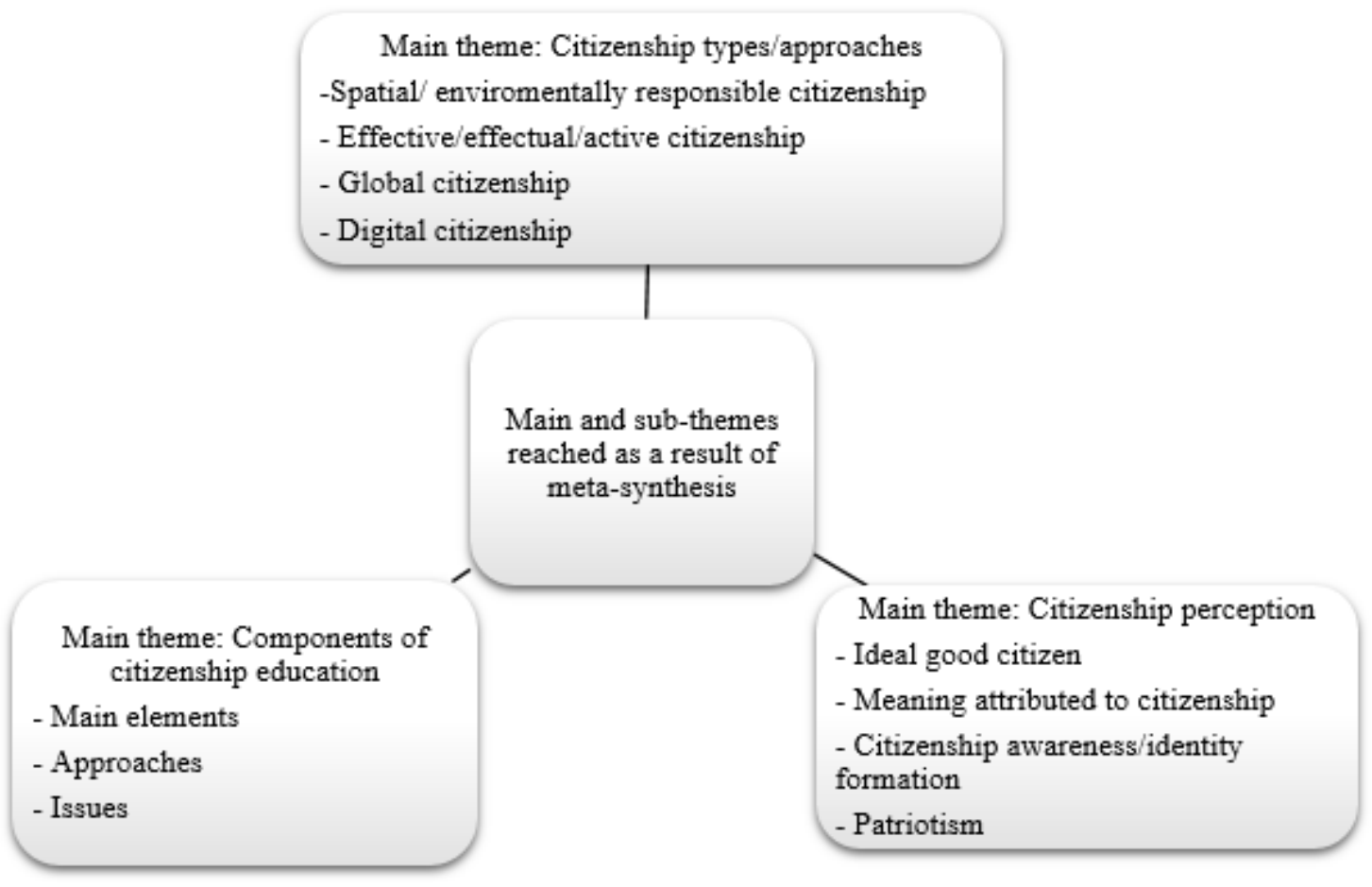

\section{Citizenship Types/Approaches}

The sub-themes and related studies obtained regarding the citizenship types/approaches, which is one of the main themes obtained in the meta-synthesis process, are given in Table 6 . 
Table 6

Sub-Themes and Related Studies on Citizenship Types/Approaches

\begin{tabular}{|c|c|c|}
\hline Main Theme & Sub-Theme & Study \\
\hline \multirow{4}{*}{$\begin{array}{l}\text { Citizenship } \\
\text { Types/ } \\
\text { Approaches }\end{array}$} & Effective/Effectual/Active Citizenship & D4, M8, M10, M11, A1, A9, A14 \\
\hline & Global Citizenship & M3, A3, A5 \\
\hline & Digital Citizenship & M1, M5, A6 \\
\hline & Spatial/Environmentally Responsible Citizenship & M2 \\
\hline
\end{tabular}

As seen in Table 6, citizenship types/approaches are addressed as spatial, environmentally responsible, effective/effectual/active citizenship, global and digital citizenship. In the studies examined, it seems that emphasis is on the characteristics of effective/active citizens (A9), the meaning attributed to the concept of effective/active citizen (M10), and effectual/active citizenship experiences (A1) within the scope of effective/effectual/active citizenship. In general, the characteristics of the effective/active citizen are explained with common characteristics (A9, M10) such as knowing and using their rights and responsibilities, fulfilling citizenship duties, having a love of homeland and nation, and being responsible.

"The characteristics of effective citizens that we aim to raise in Social Studies and citizenship lessons are individuals who know their rights and responsibilities, use them, participate, express their opinions, are open to criticism, love their nation, and embrace social values" (A9, p. 1574).

In these studies, citizenship rights/responsibilities and fulfillment of citizenship duty are included as the frequently expressed definition of effectual/active citizenship.

"In my opinion, an active citizen is an effectual person who is aware of his/her rights and responsibilities" (M9, p. 24).

With this, in studies (A1, M11, D3) that emphasize non-governmental organizations, associations or learning by service approaches within the scope of effective/active citizenship, effectual/active citizenship competencies are associated with situations such as social participation, responsibility, finding solutions to social problems, awareness of social problems. For example, in the study coded as A1, the functions of non-governmental organizations are emphasized, and it is stated that these organizations contribute to individuals' taking responsibility, social participation processes, and an understanding that focuses on active citizenship instead of a sense of duty/responsibility based citizenship. In the study coded as D3 within the scope of effective/active citizenship, it is revealed that the approach of learning by providing a service, contributes to the processes such as providing solutions to social problems, raising awareness about these problems, learning and sensitivity that can be done to reach a solution in this context.

"I am learning what it would be like to be an effectual citizen. I am learning what I can do with other citizens for the country, I would like to find solutions to different problems of the society" (D3, p. 137).

In this direction, another participants' views are as follows:

"They gather and voice the problems of the people. They talk about the issues... They defend their rights", "I learned that it is necessary to be organized. It is not very effective when 
everyone is defending something alone. As a result, more success can be achieved if we concentrate on something collectively" (A1, p. 81).

The studies included in the meta-synthesis process also included the definition, characteristics, perceptions and competencies (M3, A5) of the global citizen. In this sense, it is seen that the participants commonly emphasize universal values (M3, A5). For example, within the scope of global citizenship, the importance of having universal values and acting according to these values is emphasized in the studies coded as M3. The people who accept universal values and share a common culture are emphasized in the study coded as A5. Another common finding that draws attention as much as universal values in the context of global citizenship is the understanding of differences/tolerance (M3) and sensitivity in a global sense (M3, A5). In this context, the views of some participants are as follows:

"In other words, the important thing here is that people may be different; they may have different religious beliefs" (M3, p. 60).

When the studies within the scope of digital citizenship are examined, it is seen that the perception of digital citizenship, definition of digital citizenship, characteristics of digital citizen (M1, M5) and the state of digital citizenship (A6) are included in the curriculum and textbooks. When the participants' perception of digital citizenship is examined, it is seen that they explain it through factors such as spending much time in digital environments, keeping up with technology, using it responsibly, and concepts such as ethics, rights, law and e-government, e-signature, etc. (M1, M5). However, it has been found that the participants' digital citizenship knowledge level is low, they have superficial knowledge on this subject (M1), and there are some inadequacies regarding digital citizenship and its sub-dimensions (A6) in both social studies textbooks and curricula.

Spatial citizenship concept (M2), on the other hand, can be seen as the concepts that are less emphasized than effective/active citizenship, global citizenship and digital citizenship under the main theme of citizenship types/approaches. Within the scope of spatial citizenship (M2), the participants' spatial citizenship, the relationship of spatial citizenship with the social studies course, its place in the program, its distribution to learning areas, its relationship with values/skills, the benefits it provides to students, the problems encountered in the teaching process, and solution suggestions take place.

\section{Citizenship Perception}

The sub-themes and studies related to the perception of citizenship, another theme obtained in the meta-synthesis process, are given in Table 7.

Table 7

Sub-Themes and Related Studies on Perception of Citizenship

\begin{tabular}{lll}
\hline Main Theme & Sub-Theme & Studies \\
\hline $\begin{array}{l}\text { Citizenship } \\
\text { Perception }\end{array}$ & D1, M4, M1, M6, A11, A12 \\
\cline { 2 - 3 } & $\begin{array}{ll}\text { Ideal/Good Citizen } \\
\text { Patriotism }\end{array}$ & D1, M4, A2, A4, A7, A8 \\
\hline Citizenship Awareness/ Identity Formation & A7
\end{tabular}


In the context of citizenship perception, it is seen that the subjects of meaning attributed to citizenship, citizenship awareness/identity construction, good/ideal citizen, patriotism are taken as a basis. When the studies included in the meta-synthesis process are evaluated within the framework of "the meaning attributed to citizenship", it is seen that the participants generally express their opinions within the scope of the definition of the citizen concept and the "meaning" attributed to citizenship. In this sense, the participants define citizenship generally on the basis of belonging/commitment (M1, A11, A12). Within the scope of belonging/commitment, for example; people who are loyal to the national values and the state are among the participants' definition of the citizen concept in the study coded as M1, they consider citizenship as being related to a nation and being a member of the state in the study coded as A11, and belonging is the most frequently addressed metaphor of citizenship in the study coded as A12. Participant opinions in this context are as follows:

"Citizenship is like a vein in the body. Because it is not easily separated from the body and is connected by a bond. There is always an interaction between them" (A12, p. 2059).

In this direction, another participants' views are as follows:

"Citizenship means belonging. You belong to the country of which you are a citizen, and you have some responsibilities towards this country. These must be fulfilled. I also have responsibilities to fulfill as a Turkish citizen. It is important to know them. It must be fulfilled. For example, I cast my vote" (A11, p. 417).

Another common understanding that should be taken into account within the framework of the meaning attributed to citizenship is rights and responsibilities. In this context, it is seen that citizenship is explained on the axis of rights and responsibilities/duties by the participants (M1, A11, A12). It is seen that the participants explained citizenship from the perspective of rights and responsibilities to society (A11), expressed the importance of fulfilling their citizenship duties (A12), and saw citizenship as a set of duties (M1). In this context, paying taxes, voting, and military service are considered the most basic civic duties (M1, A11, A12). One of the common points emphasized within the context of the meaning attributed to citizenship is solidarity, unity of feelings and thoughts on a common denominator (M1, A11, A12). For example, while defining citizenship, participants emphasized the common culture and purpose in the study coded as A12. The importance of common ideal and emotion was stated in the study coded as A11, and the category of unity and togetherness came to the fore in the study coded as A12. In this regard, some of the participant views are as follows:

"Being a Turkish citizen is like being in a family of people with different characteristics. Sometimes you fight, you get offended, but you cannot give up on each other. If something happens to someone, everyone becomes one heart. In short, being a Turkish citizen means being a family" (A11, p. 417).

In the studies examined, within the scope of the concept of "good/ideal citizen," it is seen that participants' definition of good citizen, their examples, perceptions (A2, A4, A8) and the characteristics of good citizens (M4) are emphasized. In general, it is seen that the participants express their definitions of good citizenship and their explanations about the qualities that a good citizen should have on the axis of "civic duty" and "value" rather than citizenship rights and active participation. In the studies coded as D1, M4, A4, A8, it was found that within the scope of the concept of "good citizen," the participants emphasized social and moral values approved by the society, 
stated loving their state-nation, loyalty to their homeland, nation and national values as the most basic citizenship characteristic. On the other hand, there are also discourses reflecting traditional citizenship that obey the laws, pay taxes, vote (A2), in other words, see citizenship duties as more important than citizenship rights (A2, M4). For example, in the study coded as A2, participants' definitions of "good citizen" mostly emphasize traditional citizenship rather than active citizenship. Similarly, very few participants in the study coded as D1 explained good citizenship by also associating it with citizenship rights, next to citizenship duties. In addition, it is seen in the findings of the research that a tendency towards citizenship attracts more attention at the national level and the emphasis on the understanding of citizenship at the universal or global level is relatively low. In this context, in the study coded as M4, it was found that although most of the participants consider the issues that can be considered in the global framework as one of the basic goals of citizenship education, they explain the objectives that students should achieve on a national rather than global emphasis. Similarly, in the study coded as A2, it is stated that Turkish students interpret the good citizen with a more nationalist perspective compared to Russian students, while Russian students explained it with a more universal approach.

"People can be good citizens by acting properly where necessary. For example, they follow the rules, do not harm the environment, and do not disturb people with their behavior" (A2, p. 183).

"A good citizen does his military duty. Because he must learn how to defend the country" (A2, p. 188).

"My teachers explain that in order to be a good citizen, one must pay taxes. Voting is also among the characteristics of a good citizen" (A2, p. 188).

Within the scope of the concept of patriotism, participants' perspectives on patriotism perceptions, characteristics of the patriotic people, patriotism education are included (A13). In this direction, in both studies, the participants explained patriotism on common elements such as commitment, fulfilling duties and responsibilities, working, responsibility and loving. In both studies, it is stated that the participants had a constructive attitude towards patriotism. In this context, some of the participants' views are as follows:

"When I think of patriotism, the first classical phrase that comes to my mind is to love your homeland, to be loyal to it, and not to contradict what the society wants, what the state wants" (A13, p. 981).

"Fulfilling the requirements of being a citizen... is fulfilling duties and responsibilities, tax, military service. When I think of patriotism, the first thing that comes to my mind is to love your country, but loving your country is not enough..." (A13, p. 984).

\section{Components of Citizenship Education}

The sub-themes and codes created on the components of citizenship education, another of the themes obtained in the light of the studies examined, and the related studies, are given in Table 8. 
Table 8

Sub-Themes and Related Studies on The Components Of Citizenship Education

\begin{tabular}{|c|c|c|c|}
\hline $\begin{array}{l}\text { Main } \\
\text { Theme }\end{array}$ & Sub-Themes & Codes & Studies \\
\hline \multirow{8}{*}{ 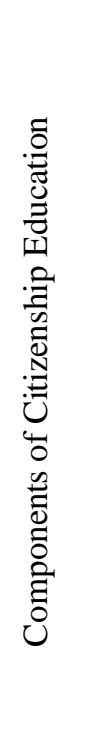 } & \multirow{4}{*}{$\begin{array}{l}\text { Basic Elements in } \\
\text { Citizenship Education }\end{array}$} & Curricula & $\mathrm{D} 2, \mathrm{M} 8, \mathrm{~A} 6, \mathrm{~A} 10$ \\
\hline & & Textbooks & $\mathrm{D} 2, \mathrm{M} 9, \mathrm{~A} 6$ \\
\hline & & Teaching Process & D2, A9 \\
\hline & & Definition/Purpose/Importance & D2, A9 \\
\hline & \multirow[t]{3}{*}{$\begin{array}{l}\text { Approaches Used in } \\
\text { Citizenship Education }\end{array}$} & $\begin{array}{l}\text { Functionality of Associations/Non- } \\
\text { Governmental Organizations }\end{array}$ & M11, A1 \\
\hline & & Learning by Serving & D3 \\
\hline & & Activity-Based Teaching & M6 \\
\hline & $\begin{array}{l}\text { Problems in } \\
\text { Citizenship Education }\end{array}$ & $\begin{array}{l}\text { Subject-Based Inadequacies, Curriculum- } \\
\text { Based Inadequacies, Incorrect Teaching of } \\
\text { Concepts And Misconceptions, Societal } \\
\text { Problems, İnstructional Problems, } \\
\text { Student-Based Problems }\end{array}$ & $\begin{array}{l}\text { D2, A9, M7, A10, } \\
\text { A14 }\end{array}$ \\
\hline
\end{tabular}

Under the main theme of components of citizenship education, three sub-themes were generated: basic elements in citizenship education, approaches in citizenship education, and problems in citizenship education.

In the first sub-theme named "Basic elements in citizenship education," the definition, objectives, and importance (D2, A9) of citizenship education take place. In general, the objectives of citizenship education are shaped on the basis of value and skills by the participants (D2, A9). When the opinions of the participants on the definition of citizenship education (D2) are examined, it is seen that they attribute it meanings similar to those they attributed to citizenship and that a citizenship education understanding based on duty/responsibility/rights is formed in this sense. In addition to this, the fact that citizenship education enables the individual to exist and socialize in society has been put forward as a common definition of citizenship education in both studies. The methods, techniques, activities, and tools used in citizenship education (D2, A9) are included in the implementation processes of the course, which is one of the elements within the scope of the first sub-theme. In this context, it is seen that there are alternatives such as lecture, question and answer, case study, drama, discussion, brainstorming, collaborative work, use of current events, use of newspaper news, game playing, role playing, use of primary sources, project, selection, drama, trip-observation, demonstration, preparing a class newspaper, preparing a class contract, and performance homework.

On the other hand, although there are many common points (lecture, questionanswer, discussion, etc.) in terms of the methods and techniques used by the participants in the studies, there is no consensus on the most preferred and the least preferred methods and techniques. For example, the most frequently used elements in the study coded as D2 are question-answer and lecture methods, while the least used elements are demonstration and six thinking hats methods. Another topic under the sub-theme of 
basic elements in citizenship education is the curriculum (D2, M9, A6, A10) and textbooks (D2, M9, A6). Within the scope of the curriculum, it is seen that the program generally focuses on the "objective" element. In this direction, sufficiency of the objectives, their applicability in daily life, the necessary methods and techniques in order to achieve them successfully, and their numbers/rates (D2, M8, A6) are included. Attention was drawn to the issues such as the objectives not being life-oriented, not meeting social needs, being abstract, and ignoring student characteristics. In the study coded as A10, which differs from other studies conducted on curriculum, instead of examining the basic elements of the curriculum, an evaluation was made in the context of political/ideological/neoliberal policies, and traditional citizenship/modern citizenship processes are introduced.

Another sub-theme that draws attention among the components of citizenship education is "approaches used in citizenship education." In this context, studies were conducted on learning by serving (D3), activity-based teaching (M6), and associations/non I governmental organizations (M11, A1). Contribution of learning by serving to good citizenship perception and citizenship education (D3), citizen competencies and contribution to responsible citizenship within the scope of activitybased education (M6) are emphasized. Within the scope of associations/nongovernmental organizations, effective citizenship experiences and citizen raising processes (A1, M11) were emphasized.

When the last sub-theme, "problems experienced in citizenship education" is evaluated, it is seen that it is explained under the following headings: subject-based inadequacies (D2), curriculum-based inadequacies (D2, A9, A10), incorrect teaching of concepts and misconceptions (D2, M7), societal problems (D2, A9), instructional problems (D2, A9), and student-based problems (A9). In this context, subject-based inadequacies are explained as the inadequacy of the subjects, the problems experienced due to the nature of the subjects, the difficulty of including some controversial issues in the classroom, the uninteresting nature of the subjects, and their being far from daily life. Program-based inadequacies are expressed as the incompatibility of the objectives to the students' level, the necessity of suitable materials for the curriculum, the activities not being clear, not being suitable for the environment, deficiencies regarding the applicability of the objectives, insufficient duration of classes, and the objectives remaining in the knowledge level. The inadequacies based on social problems are expressed as the incompatibility between the citizenship models that families want and the one in the curriculum, the inappropriate examples in the environment and media, inadequate socio-economic conditions, misconceptions in the society, and regional problems. On the other hand, instructional problems were expressed as lack of resources, the pressure created by the examination system, discipline problems in schools, crowded classrooms, inadequate facilities, lack of classroom activities, and inadequate social participation activities. Student-based problems were explained as negative student attitudes, lack of respect and responsibility, giving importance to exam-oriented subjects, and not following social problems.

\section{Discussion and Conclusion}

In many empirical studies, it has been observed that there are different understandings of citizenship and citizenship education, and these differences are also 
present among teachers, school leaders, parents, and students (Veugelers, 2011, p. 213). Brooks and Holford (2009) explain the main debates in citizenship education research as the role of schools and lifelong learning, the content of citizenship education curriculum, responding to social divisions, and national or transnational citizenship. "Citizenship is now a central concept in both politics and research when examining the role of education in developing students' identity" (Veugelers \& de Groot, 2019, p. 14). In this study, the purpose was to develop a systematic perspective on the studies based on citizenship education within the scope of social studies discipline and to reach a synthesis in this direction.

Mixed-method and basic qualitative research methods were mostly used in the studies; methods such as culture analysis, grounded theory, or ethnographic research have never been encountered. This may be due to the reasons such as the length of time these methods require, inability to associate them with the subject area of citizenship, requiring high level expertise, or the possibility of facing a large data volume. In some studies, no method was specified; only the concept of "qualitative research" was used. It is possible that this situation is caused by the lack of information about qualitative researches or overgeneralization. The fact that the majority of the studies examined were conducted with teachers or teacher candidates is likely to be due to the easier access to the participants compared to students. In addition, the most frequently used data collection tool was the semi-structured interview form and the least used one was observation. Difficulties in quantification, probable difficulties in entering the research field, the high number of participants, and the fact that it is more demanding in terms of time and money than the interview method can be seen as factors resulting in this situation.

In the light of the research examined, it has been found that the focus of the citizenship types/approaches is directed towards effectual/active citizenship, global citizenship, and digital citizenship, respectively. However, one of the striking points is that the intense interest that focuses on effectual/active, global, and digital citizenship does not focus on alternative types such as spatial or environmentally responsible citizenship. At the same time, the concept of citizenship is continually expanding, deepening, and diversifying. It is seen that "extended" citizenship is now linked not only to the national state but also to regional regulations (e.g., European citizenship) and even to the whole world through the concept of global citizenship, while "extended" citizenship means expanding from the political level to the social and cultural level (Veugelers \& de Groot, 2019, p. 14). In this context, Schugurensky and Myers (2003) offer a perspective for 21 st century citizenship education that ranges from passive to active citizenship, from national to ecological/world citizenship, from recognizing cultural diversity to promoting intercultural societies, from public sphere to inclusion, from fundamentalism to peacebuilding, from school-based citizenship to learning communities, from formal to independent democratic citizenship. In this context, it is seen that concepts such as multi/dual citizenship that can be focused on in the context of social studies, status or practice citizenship, post-national citizenship, feminist citizenship (Ünal, 2019); liberal and republican citizenship (Abowitz \& Harnish, 2006), cosmopolitan citizenship (Hutchings \& Dannreuther, 1999; Linklater, 1998); regional citizenship (Hettne, 2000); transnational citizenship (Bauböck, 1994; Hammar, 1996; Ünal, 2019) are not included. Whereas, considering the deepening and expanding nature 
of the concept of citizenship, it does not seem possible for the social studies course to exist without these processes of change.

In the theme of citizenship types and approaches, it is seen that the definition, characteristics, and competencies of citizenship types/approaches are examined. In this context, one of the points that should be noted is that the current citizenship understanding of the participants follows a course in parallel with the traditional understanding of citizenship, such as fulfilling citizenship duties even in "effectual/active" citizenship, prioritizing duties rather than rights, love of homeland, nation, and responsibility. Similarly, within the scope of the citizenship perception theme, it is seen that they focus on the definition, characteristics, and competencies of the meaning of good/ideal citizen that are frequently attributed to citizenship. Similar to the previous main theme, it is seen that participants express their opinions on the axis of belonging, loyalty, common thought and feeling unity, rights/responsibilities and duty. In general, it is stated that value/tradition-oriented citizenship understanding is addressed more frequently than active/participatory and critical citizenship understanding. Whereas, since citizenship is a complex concept that includes multiple dimensions, it should not be built only on concepts such as duty/right/responsibility/commitment or belonging. The concept of citizenship has multiple components, ranging from a legal status (e.g., rights and/or passport) to a range of behaviors (e.g., voting and/or volunteering), rights (e.g., social benefits payments) and expectations (e.g., civil norms regarding tax payment) (Keating, 2016, p. 36). In this context, Hébert and Sears (2001) draw attention to the civil, political, socio-economic, and cultural aspects. Civic sphere expresses a way of life in which citizens define and follow common goals related to their understanding of democratic society; political sphere, the right to vote and political participation, free political elections; the socioeconomic sphere, the relationship between individuals in the society, the definition of social and economic rights, economic welfare rights; the cultural sphere, the way societies react to the increasing cultural diversity, other cultures, global migration, and diversity (Hébert \& Sears, 2001). Therefore, as a multi-dimensional and layered element, it is important to enrich the meaning attributed to the ideal/good citizen and citizenship in terms of being participatory and critical by separating from the traditional "passive" approach.

In these studies, it can be seen that there is a citizenship perspective that emphasizes social/moral values approved by the society, love for the homeland-nation, adherence to national values, that is more nationalist than universal, more socialist than individualistic. In this context, it is controversial how functional a citizenship perception and education design will be in responding to different citizenship perspectives in the rapidly changing and transforming world. For example, according to Dağ (2013, p. 110) “... in societies where society has ontological priority to the individual - like ours - the foundation of citizenship by cleansing from national identity/nationality can cause shrinkage of the collective consciousness and destroy the common bond that holds the society together." In addition, citizenship education has always aimed to help base society on a single national culture defined as "republican," principles of freedom, equality, fraternity, and human rights (Osler \& Starkey, 2004, p. 4). Three centuries after the French Revolution, virtually all individuals in the world are citizens of a particular nation-state (affiliated with or claiming to be democracy), and a small 
proportion of the world's population not covered by this label has been identified as "stateless" (Fischman \& Haas, 2012, p. 170). Therefore, while some studies find the understanding of citizenship shaped by a nationalist perspective to be "natural and necessary" by its nature, in some studies it can be seen that concepts such as cultural diversity, global citizenship, and transnationalism come to the fore due to the weakening of the nation-state understanding. It is stated that globalization shows citizenship approaches need to be reevaluated; the concept of citizenship has changed as citizen s acquired greater opportunities to act in new international contexts (Osler \& Starkey, 2005, p. 8). In this context, different approaches to citizenship such as an understanding of citizenship interwoven with national boundaries through belonging/loyalty or global citizenship can have an effect on citizenship education as well as citizenship perception. Whereas the concept of "education for citizenship" contains a number of uncertainties and tensions regarding different interpretations of the concept of "citizenship" (McLaughlin, 1992), and the purpose of citizenship education is considered "controversial" (Clark \& Case, 1999). However, there is a lack of causal and comparative research to reveal the variables that cause such a perception. For example, in a comparative research conducted on Korea, Germany, and the USA, it was seen that the legal and institutional dimension of citizenship in Germany and Korea is also socialist compared to the individualist and liberal understanding in the USA (Kim \& Yang, 2013). The main factors in the fact that participants in the studies carried out in Turkey have a national, traditionalist, and value-oriented understanding of citizenship may be economical, geographical, cultural, historical, and psychological factors that are effective in citizenship formation.

Within the scope of the components of citizenship education, on the other hand, it is seen that the participants' opinions on citizenship education are similar to the meanings they attribute to citizenship. In the application processes of the course, seeing the use of many different methods and techniques such as lecture, question and answer, case study method, drama, discussion, brainstorming technique, six thinking hats method, cooperative learning, use of current events, etc. can be regarded as a positive situation. Citizenship education provides students in schools with meaningful learning experiences such as role play, debates, mock trials, classroom discussions, student councils, service learning and other active learning to facilitate their development as political and social responsibility (Homana et al., 2006, p. 3). At the same time, it is noteworthy that a more "participatory" citizenship understanding is formed in studies where alternative approaches such as non-governmental organizations/associations or learning by service are used. Similarly, when the literature is examined, the primary purpose of learning by service is focused on facilitating citizenship education while preparing to live and actively participate in a democratic society (Brandell \& Hinck, 1997); it can be an effective civic education method that is a requirement for the survival of our democracy (Battistoni, 1997), and it is stated that non-governmental organizations contribute to the strengthening of active citizenship (Keyman, 2004). Under the sub-theme of problems experienced in citizenship education, there are subject area inadequacies, curriculum-based inadequacies, incorrect teaching of concepts and misconceptions, social problems/instructional problems, and student-based problems. The main point to be noted here is that the problems experienced in citizenship education are given less place than the basic elements and approaches used in 
citizenship education. Another striking result is the differences between the problems experienced in citizenship education and the solutions developed for these problems.

\section{Recommendations}

Based on the results of this study, it is important to reveal the current tendency towards citizenship education especially within the scope of social studies course. In this sense, different citizenship approaches that are gradually deepening, developing, and diversifying can be considered a focal point in future studies.

One of the points that should be noted is that the current citizenship understanding of the participants follows a course in parallel with the traditional understanding of citizenship, such as fulfilling citizenship duties even in "effectual/active" citizenship, prioritizing duties rather than rights, love of homeland, nation, and responsibility. Alternative approaches that support the process of being a participatory and critical citizen can be used instead of the traditional passive and valueoriented citizenship understanding.

In these studies, it can be seen that there is a citizenship perspective that emphasizes social/moral values approved by the society, love for the homeland-nation, adherence to national values, that is more nationalist than universal, more socialist than individualistic. It can be suggested to examine the factors that cause the formation of nationalist and socialist citizenship perception, which is frequently encountered in the studies examined. In addition, comparative studies can be carried out by expanding the databases.

\section{Conflicts of Interest}

There are no conflicts of interest in this study. 


\section{References}

Studies included in metasynthesis are indicated with a "*” mark.

Abowitz, K. K., \& Harnish, J. (2006). Contemporary discourses of citizenship. Review of Educational Research, 76(4), 653-690. https://doi.org/10.3102/00346543076004653

*Akhan, N. E., \& Çiçek, S. (2019). An example for comparative social studies teaching: the perceptions of Turkish and Russian secondary school students towards "good citizenship". Bayburt Eğitim Fakültesi Dergisi, 14(27), 177-195. https://doi.org/10.35675/befdergi.430390

*Akpinar, B. (2019). Investigation and elimination of the misconceptions related to citizenship in 4th grade primary school social studies curriculum: An action research (Master's thesis). Marmara University, Institute of Educational Sciences, İstanbul.

*Arcanl1, Ç. (2019). The social sciences teachers and prospective teachers' opinions on the field of effective citizenship learning (Master's thesis). Firat University, Institute of Education Sciences, Elaziğ.

*Aslan, S. (2016). Digital citizenship behavior of social studies teachers of primary investigation of some variables (the sample of Firat, Dicle, Siirt, Adiyaman universities) (Master's thesis). Frrat University, Institute of Education Sciences, Elazı̆̆.

Banks, J. A. (2001). Citizenship education and diversity: Implications for teacher education. Journal of Teacher Education, 52(1), 5-16. https://doi.org/10.1177/0022487101052001002

Banks, J. A., \& Nguyen, D. (2008). Diversity and citizenship education. In L., S. Levstik \& C., A. Tyson (Eds.), Handbook of research in social studies education (pp.137-154). New York: Routledge.

Bauböck, R. (1994). Transnational citizenship: Membership and rights in international migration. Göttingen: Edward Elgar Publishing.

Battistoni, R. M. (1997). Service learning and democratic citizenship. Theory into Practice, 36(3), 150-156.

*Bengiç Çolak, G. (2015). The role of service learning approach in citizenship education in the social studies course (Doctoral dissertation). Marmara University, Institute of Educational Sciences, İstanbul.

Bondas, T., \& Hall, E. O. (2007). Challenges in approaching metasynthesis research. Qualitative Health Research, 17(1), 113-121. https://doi.org/10.1177/1049732306295879

Brandell, M. E., \& Hinck, S. (1997). Service learning: Connecting citizenship with the classroom. NASSP Bulletin, 81(591), 49-56.

Brooks, R. M., \& Holford, J. A. (2009). Citizenship, learning and education: Themes and issues. https://www.researchgate.net/publication/236546901_Citizenship_Learning_Educa tion_Themes_and_Issues 
Clark, P., \& Case, R. (1999). Four purposes of citizenship education. In P. Clark \& R. Case (Eds.), The Canadian Anthology of Social Studies (pp. 17-27). Vancouver, BC: Simon Fraser University Press.

Dağ, N. (2013). A descriptive study: The qualitative transformation of citizenship and citizenship education. Eskişehir Osmangazi Üniversitesi Sosyal Bilimler Dergisi, 13(1), 105-118.

Davies, I., Gorard, S., \& McGuinn, N. (2005). Citizenship education and character education: Similarities and contrasts. British Journal of Educational Studies, 53(3), 341-358.

*Dere, İ. (2019). Metaphoric perceptions of prospective social studies teachers towards the concept of 'good citizen'. Ahi Evran University Journal of Kırşehir Education Faculty, 20(1), 434-456.

Eidhof, B. B., ten Dam, G. T., Dijkstra, A. B., \& van de Werfhorst, H. G. (2016). Consensus and contested citizenship education goals in Western Europe. Education, Citizenship and Social Justice,11(2), 114-129. https://doi.org/10.1177/1746197915626084

*Egüz, Ş. (2016). Prospective social studies teachers' perceptions of global citizenship education. International Journal of Eurasia Social Sciences, 7(24), 30-49.

*Ekici, Ö. (2018). Social studies teachers' views on the problems in citizenship education in secondary schools (Doctoral dissertation). Atatürk University, Institute of Educational Sciences, Erzurum.

*Ersoy, A. F. (2014a). Social studies teacher candidates' experiences of active citizenship: the case of non-governmental organizations. Ankara University Journal of Faculty Educational Sciences, 47(2), 65-88. https://doi.org/10.1501/Egifak_0000001338

*Ersoy, A. F. (2014b). Active and democratic citizenship education and its challenges in social studies classroom. Eurasian Journal of Educational Research, 55, 1-20. http://dx.doi.org/10.14689/ejer.2014.55.1

*Ersoy, A. F., \& Öztürk, F. (2015). Patriotism as a citizenship value: perceptions of social studies teacher candidates. Elementary Education Online, 14(3), 974-992. http://dx.doi.org/10.17051/io.2015.85864

Evans, M. (2006). Educating for citizenship: What teachers say and what teachers do. Canadian Journal of Education/Revue canadienne de l'éducation, 29(2), 410435. https://doi.org/10.2307/20054170

*Fidan Mizrak, N. (2019). Analysis of the thoughts of social studies teachers about active citizenship qualifications (Master's thesis). Marmara University, Institute of Educational Sciences, İstanbul.

Finfgeld, D. L. (2003). Metasynthesis: The state of the art-so far. Qualitative health research, 13(7), 893-904. https://doi.org/10.1177/1049732303253462

Fischman, G. E., \& Haas, E. (2012). Beyond idealized citizenship education: Embodied cognition, metaphors, and democracy. Review of Research in Education, 36, 169196. https://doi.org/10.3102/0091732X11420927 
Geboers, E., Geijsel, F., Admiraal, W., \& ten Dam, G. (2013). Review of the effects of citizenship education. Educational Research Review, 9, 158-173. https://doi.org/10.1016/j.edurev.2012.02.001

*Günel, E., \& Pehlivan, A. (2016). Pre-service social studies teachers' perception of global citizenship. Journal of Education and Future, 10, 51-69.

Hammar, T. (1996). Book review: Transnational citizenship: Membership and rights in international migration. International Migration Review, 30(3), 813-814.

Hébert, Y. M., \& Sears, A. (2001). Citizenship education. Canadian Education Association.

Hettne, B. (2000). The fate of citizenship in post-Westphalia. Citizenship Studies, 4(1), 35-46. https://doi.org/10.1080/136210200110012

Hoge, J. D. (2002). Character education, citizenship education, and the social studies. The Social Studies, 93(3), 103-108. https://doi.org/10.1080/00377990209599891

Homana, G., Barber, C., \& Torney-Purta, J. (2006). Assessing School Citizenship Education Climate: Implications for the Social Studies. https://circle.tufts.edu/sites/default/files/2019-

12/WP48_SchoolCitizenshipImplicationsfortheSocialStudies_2006.pdf

Hutchings, K., \& Dannreuther, R. (1999). Cosmopolitan citizenship. New York: St. Martin's Press.

Johnson, L., \& Morris, P. (2010). Towards a framework for critical citizenship education. The Curriculum Journal, 21(1), 77-96. https://doi.org/10.1080/09585170903560444

*Kara, T., \& Atasoy, E. (2019). The research of social studies books and teaching program (2018) within the framework of digital citizenship notion and subdimension. Balıkesir University The Journal of Social Sciences Institute, 22(41), 133-154. https://doi.org/10.31795/baunsobed.581917

*Karaca, M. (2019). Investigation of the functionality of associations that contribute to education directly or indirectly for the purpose of social studies for effective citizen education: The case of Kütahya province (Master's thesis). Kütahya Dumlupinar University, Institute of Education Sciences, Kütahya.

*Kayaalp, F. (2015). Examination of social sciences coursebooks among the years 19231950 in Turkey with the extension of ideology - citizenship relationship (Master's thesis). Atatürk University, Institute of Education Sciences, Erzurum.

Kayaalp, F., \& Karameşe, E. N. (2020).Türkiye'de sosyal bilgiler eğitimi kapsamında hazırlanan "vatandaşlık" konulu lisansüstü tezlerdeki eğilimler. Ahi Evran Üniversitesi Kırşehir Ĕ̈itim Fakültesi Dergisi, 21(1), 744-786.

*Kayaalp, F., Karameşe, E. N., \& Karadeniz, O. (2018). Prospective social studies teachers' perceptions on the concept of "citizen (ship)". International Journal of Eurasia Social Sciences, 9(34), 2051-2068.

Keating, A. (2016). Educating tomorrow's citizens: what role can schools play?. Foro de Educación, 14(20), 35-47. http://dx.doi.org/10.14516/fde.2016.014.020.004

Keating, A., Ortloff, D. H., \& Philippou, S. (2009). Citizenship education curricula: the changes and challenges presented by global and European integration. Journal of Curriculum Studies, 41(2), 145-158. https://doi.org/10.1080/00220270802485063 
*Keleş, H., \& Tonga, D. (2014). Teacher views about factors affecting students' citizenship consciousness. Bolu Abant Izzet Baysal University Journal of Faculty of Education, 14(2), 61-85. https://doi.org/10.17240/aibuefd.2014.14.2-5000091528

Kerr, D. (1999). Citizenship education in the curriculum: An international review. School Field, 10(3/4), 5-32.

Keyman. (2004). Türkiye'de ve Avrupa'da Sivil Toplum. Retrieved from: https://stk.bilgi.edu.tr/media/uploads/2015/02/01/keyman_std_3.pdf.

*Kırıkç1, A. C. (2013). To develop citizenship competencies of social studies teacher candidates designing an activity-based model (Master's thesis). Marmara University, Institute of Educational Sciences, İstanbul.

"Kilci, Z. (2019). Social studies teachers' digital citizenship opinions and applications (Master's thesis). Anadolu University, Institute of Educational Sciences, Eskişehir.

*Kizilay, N. (2015). My social studies teacher: a good citizen in my opinion. Electronic Turkish Studies, 10(11), 987- 1006. http://dx.doi.org/10.7827

Kim, S., \& Yang, J. (2013). Patterns of citizenship and political action in Korea, Germany and the United States: An analysis of the 2004 ISSP data. In Citizenship and migration in the era of globalization (pp. 181-208). Springer, Berlin, Heidelberg.

Kuckartz, U. (2014). Qualitative text analysis: A guide to methods, practice and using software. Sage.

Leighton, R. (2004). The nature of citizenship education provision: an initial study. The Curriculum Journal, 15(2), 167-181. https://doi.org/10.1080/0958517042000226829

Linklater, A. (1998). Cosmopolitan citizenship. Citizenship studies, 2(1), 23-41. https://doi.org/10.1080/13621029808420668

McLaughlin, T. H. (1992). Citizenship, diversity and education: A philosophical perspective. Journal of Moral Education, 21(3), 235-247. https://doi.org/10.1080/0305724920210307

Ministry of National Education [MEB]. (2018). Sosyal bilgiler öğretim programı. Retrieved from: https://mufredat.meb.gov.tr/Dosyalar/201812103847686SOSYAL\%20B\%C4\%B0LG\%C4\%B0LER\%20\%C3\%96\%C4\%9ERET\%C4\%B0 M\%20PROGRAMI\%20.pdf.

*Memişoğlu, H. (2014). The education of citizenship in regard to the opinions of social sciences teachers the objective of the study. Electronic Turkish Studies, 9(5) 15651584 .

Merey, Z., Karatekin, K., \& Kuş, Z. (2012). İlköğretimde vatandaşlık eğitimi: karşılaştırmalı kuramsal bir çalışma. Gazi University Journal of Gazi Educational Faculty (GUJGEF), 32(3), 795-821.

Miles, M. B., \& Huberman, A. M. (1994). Qualitative data analysis: an expanded sourcebook. California: SAGE.

Mohammed, M. A., Moles, R. J., \& Chen, T. F. (2016). Meta-synthesis of qualitative research: The challenges and opportunities. International Journal of Clinical Pharmacy, 38(3), 695-704. https://doi.org/10.1007/s11096-016-0289-2 
Nabavi, M. (2010). Constructing the 'citizen' in citizenship education. Canadian Journal for New Scholars in Education/Revue canadienne des jeunes chercheures et chercheurs en éducation, 3(1), 1-10.

*Naml Altıntaş, İ. (2016). Active citizenship attainments of prospective social studies teachers: An action research (Doctoral dissertation). Gazi University, Institute of Educational Sciences, Ankara.

National Council for the Social Studies [NCSS]. (2001). Creating effective citizens. Position Statement from the National Council for the Social Studies. https://www.socialstudies.org/sites/default/files/publications/se/6505/650511.html

Noblit, G., \& Hare, R. (1999). Meta-Ethnography: Synthesizing Qualitative Studies. Counterpoints, 44, 93-123.

Osler, A. (2011). Teacher interpretations of citizenship education: National identity, cosmopolitan ideals, and political realities. Journal of Curriculum Studies, 43(1), 1 24. https://doi.org/10.1080/00220272.2010.503245

Osler, A., \& Starkey, H. (2004). Citizenship education and cultural diversity in France and England. In J. Demaine (Ed.), Citizenship and political education today (pp: 123). Palgrawe MacMillian.

Osler, A., \& Starkey, H. (2005). Changing citizenship: Democracy and inclusion in education. Maidenhead: Open University Press.

*Öztürk, F. (2019). A narratıve inquiry of prospective soilal studies teachers' perspective on ideal citizenship (Doctoral dissertation). Gazi University, Graduate School of Educational Sciences, Ankara.

Rapoport, A. (2009). A forgotten concept: Global citizenship education and state social studies standards. Journal of Social Studies Research, 33(1), 91-112.

Ross, E. W. (2004). Negotiating the politics of citizenship education. PS: Political Science and Politics, 37(2), 249-251.

Sandelowski, M., \& Barroso, J. (2003). Classifying the findings in qualitative studies. Qualitative Health Research, 13(7), 905-923. https://doi.org/10.1177/1049732303253488

Sandelowski, M., Docherty, S., \& Emden, C. (1997). Qualitative metasynthesis: Issues and techniques. Research In Nursing \& Health,20(4), 365-371. https://doi.org/10.1002/(SICI)1098-240X(199708)20:4<365::AIDNUR9>3.0.CO;2-E

Schugurensky, D., \& Myers, J. P. (2003). Citizenship education: Theory, research and practice. Encounters in Theory and History of Education, 4, 1-10. https://doi.org/10.24908/eoe-ese-rse.v4i0.655

Schwarz, B., Claros-Salinas, D., \& Streibelt, M. (2018). Meta-synthesis of qualitative research on facilitators and barriers of return to work after stroke. Journal of Occupational Rehabilitation, 28(1), 28-44.

Sears, A. M., \& Hughes, A. S. (1996). Citizenship education and current educational reform. Canadian Journal of Education/Revue canadienne de l'education, 21(2), 123-142. 
Sim, J. B. Y. (2008). What does citizenship mean? Social studies teachers' understandings of citizenship in Singapore schools. Educational Review, 60(3), 253-266. https://doi.org/10.1080/00131910802195836

Sim, J. B. Y., \& Print, M. (2005). Citizenship education and social studies in Singapore: A national agenda. International Journal of Citizenship and Teacher Education, 1(1), 58-73.

Som, İ., \& Karataş, H. (2015). Türkiye'de vatandaşlık eğitimi üzerine bir inceleme. Uşak Üniversitesi Ë̆itim Araştırmalarl Dergisi,1(1), 33-50. https://doi.org/10.29065/usakead.232402

Sönmez, Ö. F., Merey, Z., \& Kaymakcı, S. (2009). Vatandaşlık ve insan hakları alanında yapılan yüksek lisans ve doktora tezlerinin değerlendirilmesi. I. Uluslararası Avrupa Birliği, Demokrasi, Vatandaşlık ve Vatandaşlık Eğitimi Sempozyumu, 28-30 Mayıs, Uşak.

*Şen, A. (2019). Changes and continuities in citizenship education: what kind of citizenship education does the 2018 social studies programme of study envisage? Journal of Qualitative Research in Education, 7(1), 1-28. https://dx.doi.org/10.14689/issn.2148-2624.1.7c1s.1m

*Tatan, M. (2016). The effect of teaching social science on citizenship sense for foreign national students: Tokat sample (Master's thesis). Gaziosmanpaşa University, Institute of Educational Sciences, Tokat.

'Turan, S. (2018). Teachers' opinions on the teaching of spatial citizenship in social studies (Master's thesis). Kastamonu University, Institute of Social Sciences, Kastamonu.

"Tünkler, V. (2020). Social studies teachers' perspectives on global, multicultural education and global citizenship education. Milli Ë̆itim Dergisi, 49(226), 255-290.

Ünal, F. (2019). Vatandaşlık yaklaşımları. Vatandaşlık bilinci karma araştırma örneği. Ankara: Pegem.

*Ünlü, A. (2019). Social studies teachers' perceptions of global citizenship and their views about global perceptions citizenship education in social studies lesson (Master's thesis). Kütahya Dumlupinar University, Institute of Educational Sciences, Kütahya.

Veugelers, W., \& de Groot, I. (2019). Theory and practice of citizenship education. In Education for democratic intercultural citizenship (pp. 14-41). Brill Sense.

Veugelers, W. (2011). Theory and practice of citizenship education. The case of policy, science and education in the Netherlands. Revista de Educacion, (1), 209-224.

Walsh, D., \& Downe, S. (2005). Meta-synthesis method for qualitative research: a literature review. Journal of Advanced Nursing, 50(2), 204-211. https://doi.org/10.1111/j.1365-2648.2005.03380.x

Yalçın, A., \& Akhan, N. E. (2019). An investigation into the social studies programs from the early republic to the present in terms of social studies teaching approaches. Journal of Theoretical Educational Science, 12(3), 842-873. https://doi.org/10.30831/akukeg.414578

*Yiğit, E. Ö. (2017). Citizenship and Turkish citizenship in views of pre-service social studies teachers. Elementary Education Online, 16(2), 406-427. 
Zimmer, L. (2006). Qualitative meta-synthesis: a question of dialoguing with texts. Journal of Advanced Nursing, 53(3), 311-318. https://doi.org/10.1111/j.13652648.2006.03721.x 